\title{
Desfazendo o gênero: a teoria queer de Judith Butler
}

\author{
Eurídice Figueiredo
}

Resumo: O artigo propõe uma leitura do livro Problemas de gênero, de Judith Butler, que questiona a distinção sexo/gênero, problematizando a construção variável da identidade. Aborda a teoria queer, tentando explicar conceitos como performance e performatividade, usadas por Butler para analisar o caráter construído do gênero. $\mathrm{O}$ artigo fornece algumas pistas de leitura de obras literárias que problematizam o gênero e encenam a androginia, e conclui com fatos noticiados por jornal que permitem perceber a relevância de se refletir sobre essa questão.

Palavras-chave: teoria queer; Judith Butler; performance e performatividade; androginia; transgênero; lesbianidade.

\section{Undoing gender: Judith Butler's queer theory}

Abstract: This article proposes a reading of Judith Butler's book Gender Trouble, which discusses the distinction between sex and gender, questioning the variable construction of identity. It focuses on queer theory, in an attempt to explain concepts such as performance and performativity, employed by Butler to analyze the socially constructed nature of gender. This article gives some suggestions for the reading of literary novels that address issues related to gender trouble and androgyny and concludes with some facts published in the press that serve to make us aware of their importance.

Keywords: queer theory; Judith Butler; performance and performativity; androgyny; transgender; lesbianism.

* Docente do Programa de Pós-Graduação em Estudos de Literatura da Universidade Federal Fluminense. Contato: euridicefig@gmail.com 


\section{Crítica do sujeito, crítica da distinção sexo/gênero}

O livro de Butler, Problemas de gênero, publicado em 1990, provocou uma revolução nas hostes feministas porque contrariava alguns dogmas. Ao questionar a distinção sexo/gênero e ao problematizar a razão de o sujeito do feminismo ser "as mulheres", Butler apontava para a chamada "heterossexualidade compulsória" imposta pelas instâncias reguladoras do poder, ou seja, pelo discurso hegemônico. Dessa forma, ela visava abrir caminho para uma "construção variável da identidade" (BUTLER, 2010, p. 23), que incluiria não só as lésbicas como também os transexuais e os intersexuais. Ela sinalizava, assim, o caráter construído de todas as identidades.

Enquanto as teorias feministas sempre trabalharam com a categoria "mulher/mulheres", que seria o sujeito que procuravam promover e ao qual buscavam dar visibilidade e força política, Judith Butler colocava em xeque essa categoria afirmando que não se pode mais conceber esse sujeito "em termos estáveis ou permanentes" (BUTLER, 2010, p. 18). Ela postulava que, para delimitar o sujeito, é necessário excluir e naturalizar; ela rejeitava esse gesto, recusando, assim, o caráter essencialista do sujeito "mulher".

Por outro lado, se essas mesmas teorias feministas postulavam uma distinção entre sexo e gênero, sendo que o primeiro corresponderia ao domínio anatômico (biológico) e o segundo ao domínio sociocultural, Judith Butler afirmava que tanto o sexo quanto o gênero são construídos socialmente, portanto não é possível conceber o primeiro como natural.

Se o caráter imutável do sexo é contestável, talvez o próprio construto chamado 'sexo' seja tão culturalmente construído quanto o gênero; a rigor, talvez o sexo sempre tenha sido o gênero, de tal forma que a distinção entre sexo e gênero revela-se absolutamente nenhuma. Se o sexo é, ele próprio, uma categoria tomada em seu gênero, não faz sentido definir o gênero como a interpretação cultural do sexo (BUTLER, 2010, p. 25).

Vladimir Safatle lembra que o conceito de gênero apareceu no campo clínico em 1968 no livro Sexo e gênero de Robert Stoller. "Tratava-se de insistir em um regime próprio de formação das identidades sexuais, para além de seu vínculo estrito à diferença anatômica de sexo" (SAFATLE, 2015, p. 174). Essa distinção entre gênero e sexo passou a ser utilizada pelas teorias feministas a fim de dar ênfase ao caráter construído da identidade das mulheres.

A ideia de Butler se alicerça na conviç̧ão de que não se pode separar corpo e mente, tal como faz a filosofia ocidental. Segundo ela, o corpo não tem nada de natural, ele é construído à medida que a criança é educada pelos instrumentos sociais de poder que a levam a se transformar em uma mulher, segundo os códigos vigentes, como já advertira Simone de Beauvoir no seminal $O$ segundo sexo, obra de 1949. Apesar de concordar com muitas das análises da escritora francesa, Butler critica sua concepção humanista do sujeito, "pessoa substantiva, portadora de vários atributos essenciais e não essenciais" (BUTLER, 2010, p. 29); indo de encontro às teorias feministas que consideram o gênero como um atributo do sujeito, Butler vê o gênero sempre em relação. Em termos políticos isso se manifestaria numa forma de solidariedade que não exclui as contradições e as divergências. Seu 
ideal normativo seria a incompletude, livre de qualquer força coercitiva. "O gênero é uma complexidade cuja totalidade é permanentemente protelada, jamais plenamente exibida em qualquer conjuntura considerada" (BUTLER, 2010, p. 37), portanto, sem telos normativo.

Desconstruindo toda consideração essencialista sobre o sujeito "mulheres", Butler aponta para o fato de que, ao lado de gêneros inteligíveis, que têm relação de coerência e continuidade entre sexo, gênero e sexualidade, há aqueles que parecem ser falhados, como é o caso dos transgêneros e intergêneros. Sua proposta é, então, de criar e disseminar "matrizes rivais e subversivas de desordem do gênero" (BUTLER, 2010, p. 39) para enfrentar o falocentrismo que propugna a heterossexualidade compulsória.

Ao se indagar até que ponto a pessoa pode desafiar a autoridade/a lei, Butler invoca Foucault: "ao afirmar que sexualidade e poder são coextensivos, refuta implicitamente a postulação de uma sexualidade subversiva ou emancipatória que possa ser livre da lei” (BUTLER, 2010, p. 53). Nesse sentido, tanto a heterossexualidade sancionada quanto a homossexualidade transgressora são produzidas pela lei/dentro da lei. Não existe, pois, sexualidade antes ou depois do poder. No entanto, "operar no interior da matriz de poder não é o mesmo que reproduzir acriticamente as relações de dominação" (BUTLER, 2010, p. 55). Embora ninguém esteja fora da engrenagem do poder, Butler vê possibilidades de agenciamento ${ }^{1}$ já que as pessoas podem contestar as imposições da lei por atos de rebelião e de questionamento. Deleuze e Guattari criaram o conceito de agenciamento no livro Kafka, por uma literatura menor (1975), postulando que não há enunciados individuais, todo agenciamento é coletivo e engendra desterritorializações e reterritorializações, ou seja, a cada desterritorialização se segue uma nova reterritorialização, em constante devir. Butler se apropria do conceito de devir ao se referir ao tornar-se mulher de Beauvoir, "mulher é um termo em processo, um devir, um construir de que não se pode dizer com acerto que tenha uma origem ou um fim. Como uma prática discursiva contínua, o termo está aberto a intervenções e re-significações" (BUTLER, 2010, p. 59. Grifo da autora). Ela concebe o gênero como um devir que pode dar a aparência de uma cristalização, de algo definitivo, mas de fato é movente, não cessa de se transformar. "O gênero é a estilização repetida do corpo, um conjunto de atos repetidos no interior de uma estrutura reguladora altamente rígida, a qual se cristaliza no tempo para produzir a aparência de uma substância, de uma classe natural de ser" (BUTLER, 2010, p. 59). Em outras palavras, o gênero (ser mulher) não é nem uma substância, nem uma coisa natural e definitiva. Ao chegar nesse ponto de raciocínio, Butler interroga a pertinência da própria noção de sujeito porque ela quer priorizar a ação e não o agente; por essa razão, ela diz que não existe fazedor, só os feitos (BUTLER, 2010, p. 49).

Safatle assinala que o livro de Butler se situa num momento marcado por dois fenômenos centrais nos Estados Unidos: 1. o advento das reivindicações das minorias e de grupos socialmente minoritários como o das mulheres; 2. a mudança em relação à homossexualidade que deixa de ser considerada uma perversão pelo DSM III (Manual Diagnóstico e Estatístico de Transtornos Mentais). Na Europa, havia muitas disparidades: se na França a homossexualidade masculina era livre desde o final do século XVIII, na Inglaterra, ela só se tornou legal em 1967. Dentre os muitos casos rumorosos que aconteceram na Inglaterra, pode-se citar o da condenação do escritor Oscar Wilde, que ao sair da prisão em 1897 foi morar em Paris, onde morreria três anos depois. 


\section{Performance, performativo e teoria queer}

Safatle explica que a palavra queer, cujo sentido original era bizarro, excêntrico, estranho, passou a designar depreciativamente os homossexuais a partir do século XIX. Nos anos 1980, porém, a palavra foi reivindicada pelos grupos LGBT num processo de ressignificação em que se tornou valorativa. Com essa transformação de sentido, o termo começou a ser usado no sintagma "teoria queer", inicialmente pela feminista italiana Teresa de Lauretis (SAFATLE, 2015, p. 178). Guacira Lopes Louro afirma que o queer é o sujeito da sexualidade desviante que não deseja ser integrado, nem tolerado; "é um jeito de pensar e de ser que não aspira o centro nem o quer como referência; um jeito de pensar e de ser que desafia as normas regulatórias da sociedade, que assume o desconforto da ambiguidade, do 'entre-lugares', do indecidível” (LOURO, 2016, p. 7-8). Ela salienta que o termo queer teve seu significado ampliado nos anos 1990 e passou a ser usado "no âmbito teórico e político para indicar uma posição ou disposição de contestação e de não conformidade em relação às normas, processos de normalização ou cânones de qualquer ordem" (LOURO, 2017, p. 37). Assim, podemos concluir que queer tem, pelo menos, duas vertentes: de um lado, é uma atitude existencial que se reflete no comportamento transgressivo que não respeita a heteronormatividade e, de outro lado, é uma teoria que busca estabelecer princípios e criar dispositivos que levem a uma ruptura de valores impostos pela doxa.

Teresa de Lauretis, no artigo "Tecnologia do gênero" (1987), já criticava a noção de gênero baseada na diferença sexual, mostrando que ela permanecia atada aos termos tradicionais do patriarcado; também apontava para a importância de outros elementos como classe e raça na constituição do sujeito. Como Butler, ela relê a questão a partir de Foucault, adotando a noção de "tecnologia sexual", ou seja, o fato de que a sexualidade é resultado de um conjunto de ações sociais que engendram comportamentos e relações sociais. Todavia, seu argumento se distingue do de Foucault por uma razão bastante elementar: a partir de seu lugar de fala, ela tem consciência de que existe uma diferença de percepção em relação à história da sexualidade de homens e de mulheres. Dessa maneira, "ao pensar o gênero como produto e processo de um certo número de tecnologias sociais ou aparatos biomédicos” (LAURETIS, 1994, p. 208), ela redimensiona a questão da tecnologia sexual colocada por Foucault apontando para o fato de que os apelos de sujeitos masculinos e femininos se diferenciam.

Teresa de Lauretis assinala que, para além da construção do gênero imposta pelas várias tecnologias, ela vislumbra possibilidades de construção diferente de gênero nas margens dos discursos hegemônicos. Se concebidos fora do contrato social heterossexual, e, quando inscritos em práticas micropolíticas, "tais termos podem também contribuir para a construção do gênero e seus efeitos ocorrem ao nível 'local' de resistências, na subjetividade e na autorrepresentação" (LAURETIS, 1994, p. 228).

O pensamento de Paul B. Preciado também tem pontos comuns com a teoria queer de Butler, ainda que haja divergências entre eles. Na trilha de Foucault, como Butler e de Lauretis, ele postula que o "sexo é uma tecnologia de dominação heterossocial que reduz o corpo a zonas erógenas em função de uma distribuição assimétrica de poder entre os gêneros" (PRECIADO, 2017, p. 25). 
Butler demonstra que o gênero é "performativamente produzido e imposto pelas práticas reguladoras da coerência de gênero" (BUTLER, 2010, p. 48. Grifos da autora), ou seja, a identidade de gênero é performativamente constituída. Como explica Sara Salih, Butler se apropria do conceito de performativo de Austin, segundo o qual haveria enunciados constativos, que ele chama de atos perlocutórios, e os enunciados performativos, os atos ilocutórios: os primeiros descrevem ou relatam algo enquanto os performativos realizam aquilo que é dito, como no exemplo "Eu os declaro marido e mulher", frase que realiza o casamento de duas pessoas (SALIH, 2017, p.124). Os atos que regem a formação da identidade do gênero são performativos porque são fabricados tanto por sinais corporais quanto por meios discursivos. Em decorrência disso o gênero não pode ter um caráter ontológico.

Se a verdade interna do gênero é uma fabricação, e se o gênero verdadeiro é uma fantasia instituída e inscrita sobre a superfície dos corpos, então parece que os gêneros não podem ser nem verdadeiros nem falsos, mas somente produzidos como efeitos de verdade de um discurso sobre a identidade primária e estável. (BUTLER, 2010, p. 195)

Além do performativo, Butler usa também o conceito de performance, sobretudo aplicado às drags queens que performam o gênero, com efeito paródico de qualquer gênero. A performance é uma realização mais individual, enquanto o performativo é uma noção aplicada ao discurso coletivo que constrói os gêneros. Butler reconhece que nem toda paródia é subversiva, ou seja, é preciso indagar que tipo de relação se estabelece entre produtor e receptor, entre performer e público, a fim de perceber se a paródia tem efeitos disruptivos ou se ela é totalmente domesticada. Em sua linguagem pouco assertiva e mais problematizadora, ela indaga:

Que performance inverterá a distinção interno/externo e obrigará a repensar radicalmente as pressuposições psicológicas da identidade de gênero e da sexualidade? Que performance obrigará a reconsiderar o lugar e a estabilidade do masculino e do feminino? E que tipo de performance de gênero representará e revelará o caráter performativo do próprio gênero, de modo a desestabilizar as categorias naturalizadas de identidade e desejo? (BUTLER, 2010, p. 198. Grifos da autora)

O discurso individual pode ser ao mesmo tempo uma performance com um efeito performativo quando, por exemplo, ela é interpelada por um rapaz que, provocativamente, lhe pergunta se ela é lésbica. Ao se declarar lésbica publicamente, como forma de afirmação identitária, ela transforma uma simples frase em um ato de agenciamento, trazendo visibilização para um grupo que a sociedade hegemônica busca invisibilizar porque, como assinala Adrienne Rich, mais do que os homossexuais masculinos, as lésbicas não são visíveis. A doxa procura não vê-las.

A performance se faz performatividade queer, como explica Paul B. Preciado: "a força política da citação descontextualizada de um insulto homofóbico e da inversão das posições de 
enunciação hegemônicas que este provoca". Preciado é mais radical que Butler ao postular que o gênero não é simplesmente performativo, ou seja, um efeito das práticas discursivas, ele só se dá na materialidade dos corpos (PRECIADO, 2017, p. 28-29). Apesar dessa crítica de Preciado, é preciso salientar que Butler também leva em consideração a materialidade dos corpos, pois ela afirma que o gênero se constrói como um ato, um estilo corporal, já que não há uma essência que o anteceda; intencional e performativo, o gênero é uma performance, uma "construção que oculta normalmente sua gênese" (BUTLER, 2010, p. 199). O gênero, que não é algo estável e permanente, se constitui ao longo do tempo "por meio de uma repetição estilizada de atos" (BUTLER, 2010, p. 200. Grifos da autora). Como o gênero não é uma substância fixa, não há falso nem verdadeiro, original ou imitativo.

O fato de a realidade do gênero ser criada mediante performances sociais contínuas significa que as próprias noções de sexo essencial e de masculinidade e feminilidade verdadeiras ou permanentes também são constituídas, como parte da estratégia que oculta o caráter performativo do gênero e as possibilidades performativas de proliferação das configurações de gênero fora das estruturas restritivas da dominação masculina e da heterossexualidade compulsória. (BUTLER, 2010, p. 201. Grifos da autora)

\section{Travestismos}

Para contextualizar o livro de Butler numa nova onda do feminismo é pertinente lembrar que ela surge após o advento da AIDS, chamada na década de 1980 de "praga gay", "câncer gay". Se a homossexualidade já era estigmatizada, a visão do homossexual como abjeto foi reforçada com o surgimento da doença, que afetou sobretudo a comunidade gay. É no âmbito da discriminação e da guetização que feministas lésbicas lançam mão do conceito de heterossexualidade compulsória, numa atitude de agenciamento que visa a reterritorializar a lesbianidade. $\mathrm{O}$ próprio termo lesbianismo é recusado por Adrienne Rich, que o considera como parte do vocabulário médico.

Butler trata da AIDS no livro Problemas de gênero, mostrando que haveria a construção de uma continuidade entre o estatuto poluído do homossexual devido à violação de fronteiras e a doença "como modalidade específica de poluição homossexual". Ela argumenta que a homossexualidade é concebida "tanto como incivilizada quanto como antinatural" (BUTLER, 2010, p. 189/190)

Butler investe na figura do travesti e da drag queen a qual se mostra muito produtiva em sua demonstração do caráter construído do gênero. O travesti e o drag em suas performances fazem uma paródia de gênero, demonstrando o caráter factício de todo gênero, a não-existência de um original autêntico. Ela cita Esther Newton:

Em sua expressão mais complexa, [o travesti] é uma dupla inversão que diz que a "aparência é uma ilusão". O travesti diz [...]: "minha aparência externa é feminina, mas minha essência interna [o corpo] é masculina". Ao mesmo tempo, simboliza a inversão oposta: "minha aparência 
externa [meu corpo, meu gênero] é masculina, mas minha essência interna [meu eu] é feminina" (BUTLER, 2010, p. 195-196)

Butler assinala que nem toda paródia tem caráter transgressivo. Muitos filmes blockbusters tiveram travestismos edulcorados, como se diz na França bon chic bon genre, que não passam de clichês que acabam reforçando estereótipos. Apesar de não dar exemplos, nem entrar realmente na questão do cinema, alguns filmes podem ser evocados como Tootsie (de Sidney Pollack, 1982, com Dustin Hoffman), Victor ou Victoria (de Blake Edwards, 1982, com Julie Andrews) e outra comédia, bem anterior, Quanto mais quente melhor (de Billy Wilder, 1959, com Jack Lemmon e Tony Curtis).

Se nas teorias feministas mais tradicionais o travestismo era encarado como degradante, na teoria queer de Butler o seu lado performático é, ao contrário, valorizado porque desmistifica a naturalização do gênero, ou seja, ao imitar o gênero, o drag revela o seu caráter imitativo. "A performance do drag brinca com a distinção entre a anatomia e o gênero que está sendo performado. Mas estamos, na verdade, na presença de três dimensões contingentes da corporeidade significante: sexo anatômico, identidade de gênero e performance de gênero" (BUTLER, 2010, p. 196. Grifos da autora). Entretanto, Preciado salienta que as comunidades transgêneros nos Estados Unidos criticaram a instrumentalização da performance da drag queen de Butler, que teria ignorado tanto as transformações reais que acontecem nos corpos "quanto as técnicas de estabilização do gênero e do sexo que operam nos corpos heterossexuais" (PRECIADO, 2017, p. 93).

\section{construção do gênero na literatura}

Indicarei algumas pistas de leituras de obras literárias de Balzac, Ben Jelloun, Guimarães Rosa, Natália Polesso, Marcia Tiburi e Amara Moira, que encenam esse caráter construído do gênero, sem a pretensão de fazer uma análise mais aprofundada de nenhuma delas. Só vou tratar de obras modernas e contemporâneas, mas vale a pena lembrar que o mito do andrógino já existia na Antiguidade, tendo sido tratado por Platão em $O$ banquete. Por outro lado, Tirésias se transformou em mulher, tendo vivido sete anos nessa condição. Cego e com o dom da profecia, Tirésias é um personagem que aparece na Odisseia de Homero e nas peças do ciclo tebano de Sófocles.

Balzac escreveu pelo menos duas novelas em que cria personagens andróginos: Sarrasine (1830) e Séraphîta (1835). Esta se passa na Noruega, é fantástica, quase mística. O personagem se desdobra em dois: na versão feminina, Séraphîta, é amada por Wilfrid, e na versão masculina, Séraphîtus, é amada por Minna. Impossibilitado de resolver esses dilemas de amores carnais, ele se torna um Serafim e voa para os céus. Já Sarrasine é realista e se passa em Paris e Roma.

Sarrasine tem duas partes, uma emoldurando a outra, pois é durante a festa na casa dos Lanty, narrada na primeira parte, que é contada a história de Zambinella, uma cantora de ópera por quem se apaixona o escultor Sarrasine. A novela foi analisada por Roland Barthes em $S / Z$.

As principais indagações levantadas na primeira parte dizem respeito à origem da fortuna dos Lanty e à identidade de um velho centenário que recebe as atenções de Madame Lanty e de seus 
filhos (Filippo e Marianinna). Trata-se de uma figura estranha cuja presença os donos da casa parecem temer. Na segunda parte o narrador conta a história de Ernest-Jean Sarrasine, jovem escultor francês ingênuo que em Roma se apaixona pela cantora de ópera chamada Zambinella. É a partir de seus desenhos e escultura da cantora, feitas no século anterior, que teriam sido confeccionadas as obras de arte admiradas pelos convidados da festa.

Tendo chegado em Roma em 1758, Sarrasine se aproxima da atriz e cantora movido por uma grande paixão. Ela tenta, inutilmente, dissuadi-lo de sua obsessão por um jogo de cena em que chega a lhe perguntar "E se eu não fosse mulher?" No entanto, cego e surdo aos apelos de Zambinella, ele não compreende nada. Até que, por fim, alguém lhe revela que na ópera italiana não havia mulheres. Os castrati, jovens castrados antes da puberdade, portanto antes de mudarem de voz, desempenhavam o papel de mulheres. Zambinella era, portanto, um homem castrado que se vestia de mulher na ópera, mas se vestia de homem ao cantar na residência do embaixador francês.

Essa paixão trágica pela bela atriz-cantora tem dois resultados: do lado positivo, ele faz desenhos e uma escultura dela, que seriam copiados por outros artistas; do lado negativo, ele é assassinado pelos homens de seu protetor, o cardeal Cicognara, após uma tentativa frustrada de sequestrar a cantora. Zambinella não é livre, é uma cortesã mantida pelo cardeal. No presente da enunciação, a Zambinella é o velhinho que transita pela festa na casa de Madame de Lanty, sua sobrinha.

Nota-se aqui a perfeição do hermafrodita que já estaria presente em seu nome se se tirar a letra Z (ambinella), ela/ele possui ambos os sexos. O Z seria, segundo Barthes (1970, p, 113), o sema do corte, da falta. Ela seduz o escultor por sua beleza, a ser transformada em arte. Essa beleza residiria em sua completude andrógina? Na sua exposição no palco? Na sua arte de cantar que sensibiliza o artista (ainda que de outra arte)?

Por outro lado, a ambiguidade também está presente no nome do personagem (e título da novela), Sarrasine que, por sua terminação em -e, denota o feminino, embora designe o sobrenome do protagonista masculino. Ele age como homem apaixonado, é motivo de riso de todos os atores da ópera que o veem como um bobo. Afirma admirar todas as fraquezas da Zambinella, acha que "detestaria uma mulher forte, uma Safo, corajosa, cheia de energia, de paixão" (BALZAC, 1970, p. 253. Tradução minha). Ironia trágica do herói que desconhece aquilo que todos sabem, inclusive os leitores, ao ver na boca do personagem essas afirmações cheias de clichês sobre as mulheres quando ele está enamorado de um homem castrado.

A ambiguidade sexual está presente em quase todos os personagens. Os dois filhos de Madame de Lanty, Filippo e Marianinna, ambos muito jovens e belos, formam um par andrógino que repete a beleza da Zambinella no passado, assim como a mãe deles, igualmente bela, imperiosa e castradora.

Se os castrati não escolhiam a sua sorte, eram criaturas malditas, emasculadas a serviço dos grandes senhores da ópera, outras razões aparecem em outras obras literárias. Em Grande sertão: veredas, de Guimarães Rosa, o personagem Diadorim assume a aparência masculina, adotando o nome de Reinaldo. Filho de Joca Ramiro, seu nome de batismo é Maria Deodorina. Conhece Riobaldo já em trajes masculinos. Riobaldo, o narrador do romance, se apaixona por ele, amor proibido já que ele não assume um amor homossexual. "Eu tinha renegado Diadorim, travei o que tive vergonha [...]. Lhe ensino: porque eu tinha negado, renegado Diadorim, e por isso mesmo logo depois era de Diadorim que eu mais gostava. A espécie do que senti. O sol entrado" (ROSA, 1965, p. 
149). Depois de uma ausência inexplicável, Diadorim volta e Riobaldo reconhece seu amor. "E de repente eu estava gostando dele, num descomum, gostando ainda mais do que antes, com meu coração nos pés, por pisável; e dele o tempo todo eu tinha gostado. Amor que amei - daí então acreditei" (ROSA, 1965, p. 182). Sente ciúme ao ver a alegria de Diadorim diante da chegada de Joca Ramiro que, naturalmente, Riobaldo não sabe ser o pai de Diadorim (ROSA, 1965, p. 189).

A homossexualidade permeia o romance ainda que de maneira arrevesada como a linguagem do autor, dando muitas voltas em torno da questão. O personagem Hermógenes, sorrateiramente, se insinua com Riobaldo na ausência de Diadorim. "- 'Será, o Hermógenes também gosta de mulher's?' - eu careci de saber, perguntei. - 'Eh. Aprecêia não'" (ROSA, 1965, p. 180).

Diadorim é um jagunço como os outros homens, enfrenta os combates, mata e morre, com grande coragem. Não tem fragilidades, características presumidas como femininas. Seu segredo só é revelado no fim do romance. Após sua morte, Riobaldo vê, estarrecido, o cadáver do companheiro que ia ser lavado. "Que Diadorim era o corpo de uma mulher, moça perfeita... Estarreci. A dor não pode mais do que a surpresa. A coice d'arma, de coronha..." (ROSA, 1965, p. 453). Essa revelação surpreende e/ou decepciona o leitor que acompanha o desenrolar do amor interdito de Riobaldo por Diadorim porque explicita aquilo que poderia ter ficado enigmático. Mas é preciso ponderar que, vivendo numa sociedade machista, Guimarães Rosa preferiu escapulir da indecidibilidade que seu texto alimentou ao longo de 450 páginas para rompê-la ao final.

L'enfant de sable de Tahar Ben Jelloun encena a construção do sexo masculino numa história em que o pai, depois de sua mulher ter dado à luz sete meninas, decide que o oitavo filho será um homem, custe o que custar. Apesar de ter nascido uma outra menina, o pai chama o bebê de Ahmed e lhe atribui o sexo masculino. A criança crescerá com todas as prerrogativas dos homens numa sociedade em que só os varões têm direito à herança. Baseado num fait divers, o romance de Ben Jelloun tem um narrador onisciente de terceira pessoa, que divide a narrativa com outras vozes, de contadores de histórias e textos escritos pelo próprio Ahmed, inclusive cartas que escreve para sua parte feminina, Zahra. A assunção da identidade feminina é explorada no fim do romance quando ele se dá conta que, ao enganar os outros, ele enganava a si mesmo (BEN JELLOUN, 1985, p. 169). Isso se amplia na continuação do romance que é La nuit sacrée.

Ahmed tem consciência de que tem um corpo de mulher, mas sua identidade social é masculina: ele se casa com uma mulher, Fatima, e exerce o poder sobre suas sete irmãs, passivas e submissas. Depois da morte do pai, torna-se o tutor delas; por outro lado, essa morte o liberta também, pois ele pode assumir a identidade feminina. Ele age como um ser superior porque tudo na sociedade marroquina o autoriza a ter esse comportamento, inclusive a religião muçulmana e a tradição.

Uma crítica à posição social inferior da mulher na sociedade marroquina perpassa todo o romance, dando-lhe um caráter satírico. A despeito do elemento trágico do personagem que não consegue definir sua identidade sexual, ficando no terreno do indecidível que o deixa frustrado, o caráter construído do gênero é muito bem explorado pelo autor que imagina cenas como a da circuncisão do bebê e a do casamento de Ahmed com Fatima, que se torna sua cúmplice.

Nessas três narrativas existe uma perfeição no travestismo, já que todos acreditam no gênero que os personagens encarnam: Zambinella, Diadorim e Ahmed. Já no romance Uma fuga perfeita é sem volta, de Marcia Tiburi, o personagem-narrador, Klaus Wolf Sebastião, é um hermafrodita 
que, após o nascimento, foi designado performativamente como homem pelos pais. Seu nome sinaliza seu hibridismo já que mistura nomes em português e em alemão. $\mathrm{O}$ personagem nunca teve vida sexual e nunca mostrou seu corpo, que lhe parece um verdadeiro incômodo.

Ao longo de quase 600 páginas, o narrador fala de sua vida, dos diferentes níveis de passado, de seu presente como empregado do museu na Alemanha, para onde emigrou, da morte do pai anunciada por telefone pela irmã que vive em Florianópolis, de sua amizade com Irene e Thomas. Só nos últimos capítulos do romance é que a questão sexual se explicita e o personagem decide se metamorfosear. Ao imaginar o que dirá a Irene, ele passa a falar de si no feminino.

Entre objetos perdidos, explicaria a ela que encontrei a mim mesma. Que sou outra pessoa. Tenho que dizer a Agnes V.P. que a vida dá muitas voltas. Tenho que explicar a Agnes que Agnes Atanassova está aqui, que Irene irá conhecê-la e que tudo está bem como jamais esteve. (TIBURI, 2016, p. 595)

Foi a morte do pai que libertou o personagem, permitindo que se transformasse. "A morte de meu pai me traz um estranho descanso, como se eu mesmo tivesse morrido para que Agnes Atanassova pudesse continuar sua meditação" (TIBURI, 2016, p. 598). E na última cena o personagem tira a roupa de mulher, veste sua velha calça preta, porém conserva o colar de pérolas no pescoço, aquele colar que evoca o quadro de Vermeer, citado algumas páginas antes. Ao final de uma vida de opressão sexual, o personagem de Tiburi ensaia uma libertação, fazendo uma metamorfose que o leva a assumir o sexo feminino, que era, desde o início de sua vida, uma possibilidade de ser, mas que foi cortada pela designação "É um menino". Como assinala Butler, esse tipo de frase é performativa porque é um ato, cria um fato ao qual não é fácil escapar, como fica claro no romance de Marcia Tiburi. Como Preciado assinala, muitas vezes os órgãos genitais não estão bem definidos e a criança tem elementos dos dois sexos, ainda que alguns possam ser um pouco atrofiados. A recomendação nesses casos é que não se atribua um sexo de maneira performativa, assegurando a possibilidade de o sujeito vir a fazer sua opção ao entrar na vida sexual, eventualmente fazendo desenvolver mais alguns órgãos com uso de hormônios.

A transformação corporal e a performance de gênero são apresentadas por Amara Moira, autora de E se eu fosse puta?. Ela conta no livro que fez a transição na Parada Gay de 2014, quando foi maquiada por uma drag queen, que lhe emprestou roupas femininas. Foi a primeira vez que teve coragem de se olhar no espelho e se ver como mulher. "Coisas mudam quando você se lança de cabeça na transição, o andar, a postura, a forma de interagir com as pessoas, o tom da voz, coisas que vivo como um desafio autoimposto mais do que uma obrigação" (MOIRA, 2016, p. 54).

O espelho que aparece tanto aqui quanto no romance de Tiburi aponta para a questão da autoimagem, a visão do próprio corpo como identidade sexual. Nos dois casos, tanto no nível ficcional quanto no nível autobiográfico, os dois personagens fazem a transição de homem para mulher. No caso de Amara Moira, personagem e pessoa real, a transformação do corpo se faz pelo uso de hormônios, bloqueador de testosterona, além de reformulação do gestual e das vestimentas. Paul B. Preciado, que fez a transição de mulher para homem, analisa, no Manifesto contrassexual, as várias possibilidades de cirurgias bem como o uso de próteses como o dildo. 
Ela escreve um blog e, em seguida, o livro, com o objetivo de relatar a sua experiência de doutoranda na UNICAMP, travesti e prostituta. A partir desta dupla tarefa de fazer e escrever, Amara Moira torna-se militante LGBT e viaja para encontros internacionais. Além disso, por sua posição excepcional, ao publicar seu livro em 2016, deu entrevistas aos principais jornais do país, o que contribuiu para dar maior visibilidade às questões que ela defende. Foi capa da revista TPM em setembro 2017, com a chamada "O futuro é feminino?". Na entrevista à Milly Lacombe, ela fala da importância de uma educação transformadora para mudar o comportamento violento dos homens. Ela ousou posar nua para essa matéria da TPM assim como ela ousou exercer a prostituição de rua, em condições bastante difíceis durante alguns anos. Ela se interpõe contra o feminismo radical que condena a prostituição. "Do ponto de vista do conservadorismo radical [...], é um absurdo alguém defender que mulheres possam vender prazer a um homem, negociar esse prazer, pôr a ele um preço" (MOIRA, 2016, p. 141). Amara Moira defende a regularização da profissão a fim de que as profissionais do sexo possam ter melhores condições de trabalho e critica o feminismo radical que se alia às forças mais conservadoras para combater todo projeto de lei que vise a mudar a situação atual. Ela luta por um feminismo que não deslegitime as pautas das prostitutas e o livro serve para este fim.

Para concluir essa amostra de exemplos literários que reforçam as considerações teóricas sobre a teoria queer, é interessante ver como a cena da interpelação, mencionada por Judith Butler, em seu livro Problemas de gênero, aparece transfigurada no conto "Vó, a senhora é lésbica?" do livro Amora, de Natália Borges Polesso. Numa reunião de família, o neto Joaquim faz a pergunta provocadora que causa estupefação na avó. A pequena Beatriz pergunta "o que é lésbica?", enquanto Joana, a narradora, sente medo que a pergunta tenha a finalidade de denunciá-la. Ela fala de seu relacionamento com Taís, seus beijos na biblioteca da faculdade, e rememora a amizade duradoura da avó Clarissa com Carolina, frequentadora assídua da casa, e conclui que realmente a avó deve ser lésbica. Há uma elipse, a resposta da avó não é transcrita porque a narradora se perde em divagações e só escuta que fazia vinte anos. Essa seria a marcação temporal da relação que mantinha com Carolina. Todavia, cada uma mora em sua própria casa. Joana afirma que, apesar de amigos e professores saberem sobre o relacionamento dela com Taís, ela ainda não teve coragem de falar com seus pais. Nesse conto, como na maioria dos outros, ocorre uma naturalização do amor lésbico e, eventualmente, da bissexualidade; quando existe perplexidade, ela advém do mundo exterior. Os contos de Natália Polesso enfatizam mais as relações amorosas do que as sexuais, com personagens que vão da adolescência até a velhice, passando pela idade adulta.

\section{Oqueer na midia}

Lendo o jornal $O$ Globo do dia de hoje (12/09/2017) me deparo com três matérias que apontam para a importância e a relevância da questão nos dias de hoje: o cancelamento da exposição Queermuseu, no Santander Cultural de Porto Alegre, por pressão de grupos conservadores, a entrevista da psicanalista Letícia Lanz a Diana Ferraz na seção "Conte algo que não sei" e uma reportagem sobre uma escola britânica que decidiu adotar o mesmo uniforme para meninos e meninas. 
A matéria intitulada "Diversidade" informa que a escola Priory, em Lewes, no sul da Inglaterra, que tem mais de mil alunos entre 11 e 16 anos, decidiu adotar uniformes neutros para os novos alunos a fim de evitar discriminação de gênero. Os alunos antigos não precisam adotar o novo uniforme que consiste em calças e camisas, sem gravata. Na escola estudam poucos alunos transgêneros, mas o número cresce. A decisão decorre de uma política de Estado para que as escolas sejam mais receptivas às crianças que questionam sua identidade de gênero. Iniciativa semelhante a esta foi adotada pelo Colégio Pedro II no Rio de Janeiro. No Brasil, a pressão contra qualquer política de gênero nas escolas tem sido forte e a decisão do centenário colégio carioca foi considerada polêmica; houve até uma certa galhofa na imprensa devido à permissão para que os meninos usassem saia.

A entrevista da psicanalista Letícia Lanz revela um pensamento muito próximo daquilo que foi discutido nesse artigo a partir, sobretudo, da teoria de Judith Butler. Ela critica a noção de gênero que promove a separação de pessoas, exigindo padrões de comportamento que seriam adequados a cada gênero. "Não existe um vínculo natural entre sexo de nascimento e o exercício desses papéis". Ela assinala que nas lojas de brinquedos a diferença é nítida entre o que é destinado às meninas e o que é indicado para os meninos. Gostar do brinquedo "errado", não se adequar ao seu sexo biológico, ter qualquer diferença que se apresente como "anomalia", tudo isso provoca crise nos pais, o que a leva a dizer que "as crianças sofrem intenso terrorismo de gênero". Ela cita casos de crianças que são tratadas com bloqueadores de hormônios de maneira precoce para satisfazer a ansiedade dos pais que querem "normalizar" seus filhos. Ao criticar a categoria do gênero, ela defende a liberdade de cada um por se situar como lhe aprouver.

O problema é que há uma mitologia de que órgão genital define gênero e, até dentro do gueto transgênero, acredita-se que se você fizer cirurgia e virar $100 \%$ homem ou $100 \%$ mulher, vai se enquadrar. Não vai. E esse é um dos motivos pelos quais eu luto tanto contra gênero: porque o enquadramento de gênero é um princípio jurídico, precisa constar no documento de identidade. Para mudar de nome, tem que entrar na justiça, é uma tragédia. Na sociedade, quem fere o dispositivo binário de gênero é punido, pois é visto como delinquente ou como doente. (LANZ apud FERRAZ, 2017, p. 2)

Ela é contra o gênero como sistema de separação e hierarquização das pessoas, o que não a impede de se declarar mulher, de ter feito a transição aos 50 anos e ter continuado casada com a mesma mulher, ou seja, o gênero, em termos individuais, é uma decisão que cada um pode adotar.

Daniela Name, crítica de arte e curadora, assina uma coluna sobre o fechamento da exposição "Queermuseu: Cartografias da diferença na arte brasileira". Ela escreve que a exposição de Porto Alegre "ao cartografar as diferenças, discute a alteridade de múltiplas maneiras, através de obras que não vieram ao mundo para nos dar paz. A tranquilidade nunca foi e nem será o projeto da arte" (NAME, 2017, p.6). Gaudêncio Fidelis, curador da mostra, acusou os grupos ligados ao MBL (Movimento Brasil Livre) de criar uma narrativa totalmente deturpada das obras 
apresentadas e colocá-la nas redes sociais. Lígia Canongia, curadora da exposição da fotógrafa americana Nan Goldin, no MAM (Museu de Arte Moderna), no Rio de Janeiro, em 2012, também lamentou, afirmando: "A arte é um dos raros territórios em que o cidadão pode, ou deveria poder, se manifestar sem medo de opressões. Atos de censura não só demonstram um Brasil arcaico e preconceituoso, como alimentam o desrespeito e a ignorância" (apud GOBBI, 2017, p. 6). Aliás, a mostra de Goldin também sofreu censura porque inicialmente ela se daria no espaço Oi; diante da proibição, o MAM a acolheu, o que pode acontecer com a exposição Queermuseu, que já começa a receber propostas.

A censura é lamentável, mas às vezes ela funciona como um bumerangue: se não tivesse sido cancelada, a exposição não teria recebido o destaque de mídia que acabou recebendo. Como escreveu José Eduardo Agualusa, a censura, em vez de apagar o incêndio provocado pela arte, pode funcionar como gasolina, ou seja, é um combustível que alimenta o fogo, ou ainda, como dizia Valéry, "a censura violenta torna credíveis as opiniões que ataca" (2017, p. 2).

A cena pública, principalmente com a internet, é um campo de batalha de propaganda e, nesse caso, talvez o tiro, realmente, tenha saído pela culatra. $\mathrm{O}$ fato de os grupos conservadores terem atacado as obras expostas só faz confirmar a potência da arte em quebrar tabus, derrubar paradigmas de normalidade, provocar inquietação. Como já escrevia Kafka, em carta para Pollak, "o livro [a obra de arte] deve ser um machado para quebrar o mar de gelo que há dentro de nós", ou seja, a função da arte não é a de tranquilizar. É por essa razão que obras de arte que dão testemunho dos grandes desastres do século XX não devem ter efeito apaziguador.

O debate aberto nas sociedades ocidentais sobre a desconstrução dos gêneros, até recentemente concebidos de maneira estanque, tem como principais efeitos a visibilização de grupos que eram silenciados e a maior aceitação da diferença. É preciso ter em mente que os direitos das minorias nunca são definitivos, estão sempre ameaçados. No Brasil houve algumas conquistas, porém, os grupos conservadores fazem enorme pressão em defesa do retrocesso, como se vê na recente autorização, por um juiz federal, da "cura gay". Assim, a abertura em nosso país é ainda uma pequena fresta e não uma janela escancarada. Essa pequena fresta é representada por uma parcela da população que se manifestou, de uma maneira ou de outra, contra o cancelamento da exposição Queermuseu.

Lira Neto, na Folha de S. Paulo, assinou uma coluna intitulada "Indecente é a intolerância" na qual critica a decisão em que entraram altas doses de "desinformação, moralismo, ignorância e má fé" (2017, p. C10) da parte dos que pressionaram e pusilanimidade da parte do Santander, pois inexiste na mostra qualquer incitação à pedofilia e à zoofilia. Ele destaca que as telas de Bia Lessa, acusadas de elogio da pedofilia, foram inspiradas no Tumblr "Criança viada", do jornalista Iran Gusti, que coletou fotos de pessoas que sofreram bullying na infância justamente por terem a aparência de homossexuais. Ao comentar a exposição Queer Art, em cartaz, na Tate Britain, ele aponta para a diferença entre o obscurantismo que assola o Brasil e a política pública que favorece o debate sobre as (des)construções de gênero na Inglaterra. 


\section{Considerações finais}

Partindo da análise do livro Problemas de gênero, de Judith Butler, tracei um percurso teórico sobre a teoria queer, fazendo apelo a outros autores (Preciado, de Lauretis, Salih, Safatle, Louro) com o intuito de esclarecer questões relacionadas às categorias de sujeito, sexo, gênero e sexualidade. Se a teoria fornece subsídios para pensar tanto a performatividade do discurso como as performances de gênero, tal como postula Butler, a literatura (e a arte em geral) apresenta exemplos de subjetividades em ação de maneira a suscitar a reflexão e a emoção, fazendo-nos perceber o lado construído e não natural do gênero porque, como afirma Jacques Rancière (2009, p. 58), "o real precisa ser ficcionado para ser pensado".

É através da literatura que se podem entrever as subjetividades em suas diferentes facetas, em seus estilhaços de sentidos, resíduos de experiências fraturadas pela violência do vivido. Antoine Compagnon (2009, p. 47) salienta o valor da literatura cuja propriedade reside na captação do particular que reúne "as crenças, as emoções, a imaginação e a ação, o que faz com que ela encerre um saber insubstituível, circunstanciado e não resumível sobre a natureza humana, um saber de singularidades". Assim, a literatura é o único meio de

preservar e transmitir a experiência dos outros, aqueles que estão distantes de nós no espaço e no tempo, ou que diferem de nós por suas condições de vida. Ela nos torna sensíveis ao fato de que os outros são muito diversos e que seus valores se distanciam dos nossos (COMPAGNON, 2009, p. 47).

Por essas razões, a literatura provoca a identificação do leitor, suscita a emoção e a compreensão ao mesmo tempo. A literatura desconcerta e incomoda mais que os discursos filosóficos, continua Compagnon, ela "percorre regiões da experiência que os outros discursos negligenciam, mas que a ficção reconhece em seus detalhes" (COMPAGNON, 2009, p. 50).

Em suma, só a literatura é capaz de suscitar a figuração do Outro, do diferente, daquele que não se pode conhecer se não se sair de dentro de si mesmo. Só através da literatura pode-se vislumbrar o Outro que nos habita, porque a identidade só se perfaz no encontro com a alteridade, inclusive nossa própria alteridade. Guardadas as especificidades de cada a arte, a pintura realiza algo parecido, causando um impacto no espectador que passa diante dos quadros, numa galeria ou num museu. Aqueles que pediram o cancelamento da exposição Queermuseu demonstram o medo de sair de dentro de si para ver o Outro, em suas angústias e perplexidades.

\section{notas}

1 No livro da Butler o tradutor optou pelo termo "agência", mais próximo do inglês "agency", mas prefiro usar agenciamento, que foi a tradução usada a partir do francês "agencement", criada por Deleuze e Guattari. 


\section{Referencias}

AGUALUSA, José Eduardo. "As cortinas da censura". Segundo Caderno. O Globo. 18/09/2017. p. 2.

BALZAC, Honoré de. Sarrasine. In: BARTHES, Roland. S/Z. Paris: Seuil, 1970. p. 227-258.

BALZAC, Honoré de. Séraphîta. Disponível em www.biblisem.net/narratio/balzsera.htm Consulta em 12/09/2017.

BARTHES, Roland. $S / Z$. Paris: Seuil, 1970.

BEN JELLOUN, Tahar. L'enfant de sable. Paris: Seuil,1985.

BUTLER, Judith. Problemas de gênero. Feminismo e subversão de identidade. Tradução de Renato Aguiar. Rio de Janeiro: Civilização Brasileira, 2010.

BUTLER, Judith. Relatar a si mesmo. Crítica da violência ética. Tradução de Regina Bettoni. Belo Horizonte: Autêntica Editora, 2015.

COMPAGNON, Antoine. Literatura para quê? Tradução de Laura Taddei Brandini. Belo Horizonte: Editora UFMG, 2009.

DELEUZE, Gilles, GUATTARI, Félix. Kafka, pour une littérature mineure. Paris: Minuit, 1975.

DIVERSIDADE. Calça e camisa para todos. O Globo. 12/09/2017. p. 34

FERRAZ, Diana. Conte algo que não sei. Entrevista com Letícia Lanz. "Crianças sofrem intenso terrorismo de gênero". O Globo. 12/09/2017. p. 2.

GOBBI, Nelson. Queermuseu. Artistas denunciam censura. Segundo Caderno. O Globo. 12/09/2017. p. 6

LACOMBE, Milly. A revolução precisa ser sexual. Entrevista com Amara Moira. TPM. n. 172, setembro 2017. p. 18-29.

LAURETIS, Teresa de. A tecnologia do gênero. In: HOLLANDA, Heloísa Buarque de. (org). Tendências e impasses. O feminismo como crítica da cultura. Rio de Janeiro: Rocco, 1994. p. 206-242.

LIRA NETO. "Indecente é a intolerância". Ilustrada, Folha de S. Paulo. 17/09/2017. p. C10.

LOURO, Guacira Lopes. Um corpo estranho. Ensaios sobre sexualidade e teoria queer. Belo Horizonte: Autêntica, 2016.

LOURO, Guacira Lopes. Flor de açafrão. Takes Cuts Close-ups. Belo Horizonte: Autêntica, 2017. MOIRA, Amara. E se eu fosse puta. São Paulo: Hoo Editora, 2016.

NAME, Daniela. Não há arte possível para a gente de bem. Segundo Caderno. O Globo. 12/09/2017.p. 6 POLESSO, Natália Borges. Amora. Porto Alegre: Não Editora, 2015.

PRECIADO, Paul B. Manifesto contrassexual. Práticas subversivas de identidade sexual. Tradução de Maria Paula Gurgel Ribeiro. São Paulo: N-1 Edições, 2017.

RANCIÈRE, Jacques. A partilha do sensivvel. Estética e política. Tradução de Mônica Costa Netto. São Paulo: Editora 34, 2009.

RICH, Adrienne. Heterossexualidade compulsória e existência lésbica. Revista Bagoas. Estudos gays: gênero e sexualidade. Natal, UFRN. n. 05, 2010. p. 17-44.

ROSA, João Guimarães. Grande sertão: veredas. Rio de Janeiro: José Olympio, 1965.

SAFATLE, Vladimir. Posfácio. Dos problemas de gênero a uma teoria da despossessão necessária: ética, política e reconhecimento em Judith Butler. In: BUTLER, Judith. Relatar a si mesmo. Crítica da violência ética. Tradução de Regina Bettoni. Belo Horizonte: Autêntica Editora, 2015. 
SALIH, Sara. Judith Butler e a teoria queer. Tradução e notas de Guacira Lopes Louro. Belo Horizonte: Autêntica, 2017.

TIBURI, Marcia. Uma fuga perfeita é sem volta. Rio de Janeiro: Record, 2016.

Recebido em: 21 de setembro de 2017

Aceito em: 03 de fevereiro de 2018 